\title{
Some Thoughts on Stalin's Foreign Policy
}

I have read, with the usual interest and respect, Professor Tucker's paper, "The Emergence of Stalin's Foreign Policy," and offer the following comments.

I am fully in agreement with the general thrust of the argument. I find the paper illuminating and valuable as a tracing of the elements of continuity in the development of Stalin's views on foreign policy. Our impressions differ somewhat, perhaps, when it comes to the point of Stalin's motivation, but not seriously.

Stalin's stressing of the alleged parallels between Soviet Russia's situation and that of tsarist Russia at various periods of its history I see as part of what might be called his persistent effort to borrow legitimacy: legitimacy for himself as a Russian, precisely because he was not one: legitimacy for the Soviet regime precisely because it had suppressed the Constituent Assembly and illegitimately seized power; legitimacy for his own position in the party precisely because his early connections with the party were shadowy and suspect. Most interesting, to me, is the fact that he should have sensed at so early a date the need for bolstering the party's image in the mind of the Russian masses by associating it with the traditional heroic image of the ill-treated and abused Russia.

I find myself fearing that Professor Tucker's treatment of Stalin's professed views on the capitalist encirclement will leave the reader with the impression, which Soviet propagandists have always been concerned to convey, that the hostility of the Western Powers toward the Soviet Union in the early years of the latter's existence was unprovoked and represented nothing more than the fear and anger of Western capitalists at the success of socialism in another great country. I find no reference to the fact that the Russian Communist leaders came to power breathing the most fiery and dedicated sort of hostility to the governments and political systems of the Western countries, and did their level best to subvert their populations and to bring about the overthrow of the existing governments. This was not, to be sure, very much, because their means were scanty; but the intention was clear and frankly stated.

Professor Tucker has correctly outlined Stalin's views (for example, pp. 565-66) on the world political scene in the 1920s. What strikes me about these views is their extreme erroneousness. Should this not be pointed out and emphasized?

Professor Tucker has, it seems to me, incorporated into his paper the characteristic ambiguity of Soviet statements about the "war" or the "wars" that were supposed, by the workings of the capitalist system, to come about. Never was it fully clarified, in their ideological statements, whether this was to be a war among capitalist powers, who were supposed to be divided one from another by fearful conflicts of greedy interest, or a war by all or several of them against the Soviet Union, or a series of "wars and revolutions" affecting Soviet interests and threatening Soviet involvement. I think it important to avoid this ambiguity in Western statements, because so much misuse has been made of Lenin's (or was it Stalin's?) statement about the inevitability of a final conflict between communism 
and capitalism, often taken as meaning that what was meant was an inevitable great war between Communist Russia and her allies and ourselves and our allies.

A more serious difference between Professor Tucker and myself concerns the reasons for Stalin's stavka na natsistov in the 1930s, and particularly his reluctance to favor the prospects of the German Communists for taking power. Professor Tucker attributes it, as I understand it, to Stalin's belief that conditions in Germany were such that the Communists would not be able to retain power, even if they took it. I would suggest that Stalin's reluctance to see the German Communists come to power reflected his profound distrust of their political reliability from his standpoint-his fear that they were riddled with latent Trotskyite sympathies - and his enduring anxiety lest those leading Russian Communist figures whom he was eliminating, or was determined to eliminate, from the Soviet scene enlist against him the influence of the foreign Communist parties, headed by that of Germany, the birthplace, after all, of Marxism. To which should be added Stalin's evident recognition that a successful German Communist party, possessed of the great resources of the German state, would not be likely to remain for long subservient to Russian masters but would become the first of what would later be known as "Titoist parties." 